\title{
Fiduciary Transfer of Ownership in Order to Secure the Satisfaction of Claim to Contemporary Right - Proposal De Le Lege Ferenda
}

\author{
Ekrem Salihu \\ PhD Cand., Faculty of Law, South East European University, Tetovo
}

\begin{abstract}
Fiduciary transfer of ownership in order to secure the claim satisfaction represents the form of non-possessory securing of claim satisfaction, which is experiencing the Renaissance in the transition countries and in the contemporary right. This form of non-possessory pledge right is not regulated by law in our own right, nor does it enjoy legal protection. Fiduciary transfer of property on the contemporary right and legal circulation is experiencing affirmation because of the essential advantages in relation to the real means of securing the claim satisfaction. The most important advantage of fiduciary agreements in relation to the pledge (mortgage) is the efficiency of the fulfilment of the claims, because there are no extensively long court proceedings in this institution. In addition to the fiduciary agreement, unlike the pledge right, the object that is subject to the fiduciary agreement, the debtor may keep such property under possession and may use it for the fulfilment of the obligations towards the creditor, thus offering practical benefits to the debtor itself. In the Republic of Kosovo, fiduciary agreements and fiduciary transfer of ownership are not regulated at positive rates. The author of this paper is committed to regulate this legal institute with positive provisions, i.e. the issuance of a special law for this institute, or the same to be included in the new Civil Code of Kosovo, as it is about an institute which has been applied for a long time by countries of the continental system and is experiencing renaissance also in the countries of the region (Slovenia, Macedonia, Montenegro, Croatia). The regulation of this institute with positive provisions would have a positive effect on legal circulation and faster economic development in Kosovo. At the same time, regulation of this institute with positive provisions would enable alignment and approximation of the Kosovo legislation with the European Union legislation. In this paper we will present the reasons why this institute should be regulated by special law or incorporated in the new Civil Code of Kosovo. However, despite the fact that local positive provisions do not particularly regulate the fiduciary transfer of ownership institution in order to secure the satisfaction of claim, nevertheless, this institute is not entirely excluded. Thus, the Law on Obligational Relationship of the Republic of Kosovo, in Article 429 provides for the ceding in order to secure "Where ceding is made in order to secure the claim satisfaction of the concessionaire against the cedant, the concessionary is obliged to behave with the care of a good economist, namely of a good housekeeper on the collection of ceded application and after the collection is completed, after keeping as much as it is needed to meet its demands against the cedant, shall hand him over the surplus.
\end{abstract}

Keywords: Fiduciary, Fiduciary ownership, Fiduciary transfer of ownership, pledge (mortgage) right.

\section{Introduction}

The Roman law has recognized three forms of pledge. The oldest was fiducia, then the pignus has emerged, and finally the hypotheca.

In the first two forms it comes to handing over items to the creditor (and that at fiducia in ownership, while at the pignus in possession). For that beside legal-property relations, the Obligational Relationships also appear. ${ }^{1}$

Fiducia in Latin language means a trust, because it is regarding the institution by which the debtor transfers his property on the creditor as insurance to repay his claim. Otherwise, fiducia in Roman law has preceded the right of pledge,

\footnotetext{
${ }^{1}$ Stanojević Obrad, "Rimsko Pravo", Belgrade 1988 - p. 218.
} 
respectively it is considered that the right of pledge arises on the foundations of fiduciary. ${ }^{1}$ Initially, this kind of contract is based on the parties' trust; it is concluded only between cousins and friends and was not defended by lawsuit. However, often, before all real and consensual contracts, fiducia win a special lawsuit. ${ }^{2}$

Fides has been a goddess of goodwill; a personalized symbol of the trust (loyalty) in the Roman mythology, its symbol was the symbol of two tied hands. The cult of this goddess was celebrated by the ancient Romans and the fact that the goddess appeared as a gray-haired old woman shows that respect for the word has been of fundamental value, the base of the social and political system. ${ }^{3}$

Ancient Romans have most often used this institution for fiduciary transfer of ownership with the purpose of property management (fiducia cum amico contracta) and for fiduciary transfer of ownership with the purpose to insure the claim (fiducia cum creditore contracta). ${ }^{4}$ Transfer was allowed only for Roman citizens (cives) or to other free people who had been granted commercial power (commercium) ${ }^{5}$

The development of legal instruments for insurance of the claims has started with personal responsibility - nexum, recognized in the law of XII tables. Beside the personal responsibility of the nectere debtor, in Roman law at the earliest period is presented the real insurance of the claim - fiducia cum creditore - with the transfer of the item of the debtor in the possession of the fiduciary, for the purpose of the insurance. Fiducia cum creditore in reality was kind of conditional sale of the item. The person who needed financial means, the financial means had opportunity to come through the debt. In order to secure the creditor's claim (lender), he has sold a certain item to the creditor, i.e. he has transferred the property (Mancipacio ose in jure cesio) and has received the financial means on behalf of the purchase, but in that case the parties have reached agreement (Pactum fiducie) that the creditor (lender) will return the item (again with Mancipacio ose iure in cesio) when the debtor (borrower) fulfills his obligation - repayment of the debt. ${ }^{6}$

The creditor's obligation to return the item was, at first, only of a moral nature, without a sanction. Later, the obligational sanctions have been applied, not of a legal-property nature, if the creditor alienates the item, even though the debtor has paid the debt, he cannot take it back, but he only can, by the actio fiduciary lawsuit, can claim from the creditor the compensation of the damage, where this presents the great misfortune for the debtor and could have caused damage, especially because the pledged item was usually the value greater than the amount of the debt. ${ }^{7}$

Thus, if the debtor, because he did not pay the debt, lost ownership, he could not claim the item from the others by legalproperty lawsuit. However, if the debtor paid the debt with fiduciary action, he could claim for the return of the item, or if the creditor, even pactum fiduciae, realized the item, the debtor could claim the compensation. Actio fiduciae in itself contained the infaminan, the shame that the creditor would have to suffer because he did not adhere to the trust, pactum fiduciae. On the other hand, since the creditor became the owner of the item, he could be protected by actiones in rem, with the property lawsuit - rei vindication and actio negatoria. ${ }^{8}$

At the fiducia, the creditor does not 'just stretch his hand and does not put eye' on the other's (debtor's) item, he does not take only the item, but also takes the debtor himself stripped of his rights over that item. At the pledge the creditor wins only the right to possession of the debtor's item, as well as to the realization of his right to claim the sale of such item, if the debtor does not obey his obligations to the creditor. At fiducia the creditor is entitled to ownership, he is the owner of the item, has all the strength and 'governance' that the owner has, as any exclusive owner in his item. ${ }^{9}$

\footnotetext{
${ }^{1}$ Romac, Ante, rimsko pravo, Zagreb, 1998, p. 224.

2 Pravna Encikopedija, Belgrade, 1989, p. 378/.

${ }^{3}$ Mihnea-Dan Radu, Fiducia: From Fides to trust and the new Romanian Civil Code Regulation, Valahia University • Law Study, Volume xx. Issue 2012, p. 239.

4 Stojčević Dragoljub, "Rimsko Privatno pravo", Savremena administracija, Belgrade, 1985, p. 250

${ }^{5}$ Mangatchev, Ivan P, Fiducia Cum Creditore Contracta in EU Law (September 16, 2009). Available at

SSRN: https://ssrn.com/abstract=1474199 or http://dx.doi.org/10.2139/ssrn.1474199

${ }^{6}$ Mr. sc. Zrinka Radić: Uzroci heterogenosti besposjedovnih osiguranja tražbina na pokretninama i pravima, Zbornik radova Pravnog

fakulteta u Splitu, year 52, 4/2015, p. 1009

${ }^{7}$ Asllan Bilalli\&Bedri Bakalli - E drejta Romake - p.338-339, 2015 - Prishtinë/Priština

${ }^{8}$ Dr. Ejup Statovci, E drejta e pengut-aspekte komparative, 1988, p.37.

${ }_{9}$ Dr. Ejup Statovci, ibid.
} 
The definition of the trust (good faith) itself indicates the fiduciary's damage in this institution as a result of the fiduciary contract; the creditor becomes the owner of the trusted property. Thus, he gains the 'full and complete' property and, in principle, all the advantages of the owner. This is also the main characteristic of the fiduciary contract. Thus, he has the right to exploit (usus) property, harvest fruit (fructus), and even to destroy the good (abusus). ${ }^{1}$

Recognition of Roman law into continental legal systems has been made, primarily by Justinian's codification. The Fiduciary Institute of the property transfer as a means of insurance the claim is experiencing reaffirmation in the XIX century, when legal science in the process of recognition of the Roman law begins to concentrate on other sources as well, including the Institutes of Gaius, which in detailed manner regulate fiducian. ${ }^{2}$

The Fiduciary Institute of the property transfer is first encountered in the legal and judicial practice of Germany and Switzerland. It is implemented in the function of insurance of the claim (Sicherungsübereignung), or for the purpose of foreign property management (Treuhand). The first European country which implemented the fiduciary property transfer by law was Liechtenstein, where in the law on personal economic society of 1926 we encounter this means of insurance. ${ }^{3}$

\section{CAUSES OF FIDUCIARY RE-AFFIRMATION INTO LEGAL SYSTEMS}

The fiducia at the beginning of the post-classic period arises from legal practice. The Fiduciary replaces the simplest and most appropriate ratio of the pledge - pledge of the hand (pignus). Fiducia proved unsuitable due to the formalism of the transfer of items as well as the fact that actio fiduciae had effect only between the parties. ${ }^{4}$

Classical civil codifications do not regulate fiduciary property transfer and do not even regulate fiduciary affairs. ${ }^{5}$ However, in the contemporary legal systems is an actualized interest in the Fiduciary institutes of the property transfer which is experiencing a surprise return to the conditions of the contemporary market economy. ${ }^{6}$ After the Second World War, in continental Europe, it comes to the change in insurance of claims in legal-property relations. It comes to increased credit and concession claims in the business practice of powerful creditors, and thus to the return of property transfer for the purpose of insurance, even in the legal systems that were abandoned in their entirety. ${ }^{7}$ Thus, the economic power of potential creditors led to the transformation of pledge right, extending the object of pledge right by introduction of so-called non-possession item as a pledge, then with the abandonment of the specialty principle and ultimately with the development of insurance of the non-possessive claims. ${ }^{8}$

\section{FIDUCIARY OWNERSHIP}

Fiduciary ownership is a special way of securing a creditor's claim, which means the transfer of ownership over movable or immovable property of the creditor in order to secure the claim, and with the fulfilment of the claim the creditor must return the ownership over the property in which he has acquired ownership in order to secure his claim. Whereas, if the debtor does not meet the creditor's request within the specified time limit then the debtor is obliged to hand over the item in possession to the creditor because the creditor has already acquired the right of ownership at the time of the creation of the creditor's claim.

In fiduciary ownership, the fiduciary becomes conditional owner of the trustee's item, which means that in the Register for registration of the rights or in the Register where the fiduciary ownership is noted, there is also a registered note that

\footnotetext{
${ }_{1}^{1}$ Kombe Bosombisa, Cynthia, La Protection Du Fiduciant (The Protection of the Settlor) (December 20, 2014). Available at SSRN: https://ssrn.com/abstract=2664839 or http://dx.doi.org/10.2139/ssrn.2664839/

2 Vladetić Srđan, "Fiducija u rimskom pravu i savremeni fiducijarni poslovi”, Doktorska Disertacija, Pravni fakultet Universiteta u Beogradu, Beograd, 2010, p. 243.

3 Dr. Bojan Pajtić "Problem Dopustenosti fiducijarnog prenosa svojine u nasem pravu", Zbornik radova Pravnog Fakulteta u Novom Sadu $1 / 2017$, p. 126.

${ }_{4}$ Petrak, Marko, Koncepcija generalne vindikacijske tužbe u rimskoj pravnoj tradiciji i de lege ferenda, Zbornik Pravnog fakulteta u Zagrebu, br. 5-6/2013, p. 1054.

5 Povlakić, Meliha, Fiducijarno vlasništvo u usporednom pravu i sudskoj praksi, Zbornik Pravnog fakulteta Sveucilišta u Rijeci, br. 1/2003, p. 196.

${ }_{6}^{6}$ Petrak, Marko, Rimska pravna tradicija i hrvatska pravna kultura, u: Rimsko pravo i Europa, Golden marketing-Tehnička knjiga, Zagreb, 2007, p. 176

${ }^{7}$ Gavella, Nikola; Josipović, Tatjana; Gliha, Igor; Belaj, Vlado; Stipković, Zlatan, Stvarno pravo, Narodne novine, Zagreb, 2007, p. 471.

8 Povlakić, ibid.
} 
ownership is acquired for the insurance of the claim and the fulfilment of the claim of the creditor must be the settlement of the ownership and register the ownership on behalf of the debtor (the provider of the item owned by the creditor). ${ }^{1}$

Fiduciary ownership has "two faces". In relation to the third persons, the fiduciary is the owner of the item, the trustee and fiduciary's internal affiliation, Fiduciary ownership does not have that view. Its essential feature is the lack of legal authorizations. The fiduciary is the formal-juridical owner of the item; however, he has the authority to disposition of the item, which is limited by a contractual obligation (pactum fiduciae). Trustees, fiduciaries as a non-possessory insurance mean, maintain the authorization of keeping, using and harvesting fruit. The fiduciary security item is the trustee's property, while the fiduciary ownership in the fiduciary's property. The trustee is an economic owner, while the fiduciary is the legal owner of the item. ${ }^{2}$

Fiduciary ownership is obtained on the basis of a fiduciary contract for the transfer of a property right (legal title) which must be in writing and authenticated to the notary when it comes to immovable property, as well as registration in public registers or other appropriate registers for evidencing fiduciary ownership, with the note that it has to do with the fiduciary transfer of the property right. ${ }^{3}$

\section{THE JURIDICAL NATURE OF FIDUCIARY OWNERSHIP}

The theory, when talking about the legal nature of the contract on the transfer of fiduciary ownership, mostly links them to the real means of securing the claim, using the terminology that suits this qualification. Thus, the names (which are sometimes used as synonyms for fiduciary agreements) are used, such as unsecured warranties, mortgages, non-dividend mortgages and so on. In this regard, many theorists are of the opinion "that the contract on the transfer of fiduciary ownership is a real means of securing the claim and thus belongs to the contracts on the pledge. ${ }^{4}$

The Institute of fiduciary ownership deviates from the fundamental characteristics of the classical property right, which is due to the limitation and the effect of the transfer of fiduciary ownership stemming from pactum fiduciae. The fiduciary ownership transferred to the trustee is not complete in terms of property authorizations or independent ownership, but it is a conditional right in a limited period whose fate depends on the fulfilment of the main contract the provision of which it serves. Thus, fiduciary ownership is a sui generis property which, in view of securing the principal claim, presents a type of real-estate insurance. ${ }^{5}$

\section{FIDUCIARY OWNERSHIP CAUSE}

Fiducie is abstract - the cause is not visible to third persons. There are perceptions that fiducie, as a direct economic purpose of legal contract, consists in securing the claim, and the perception that the cause of the fiduciary contract, as its direct legal purpose, is "specific" or "sui generis", so it is not possible to compare in the framework of existing classifications. ${ }^{6}$

According to German law, which for the transfer of ownership provides the abstraction principle, the transfer of ownership due to securing in the prevailing opinion is fairly abstract and non-fixture. However, the parties are free to connect the reallegal contract with any resolutive clause for the securing agreement. The possibility that the transfer of ownership for securing purpose is non-fixture is also provided by the Slovenian law, which is, in principle a causal one.

In the Republic of Croatia dominates the legal theory according to which "the fiduciary transfer of ownership with the securing purpose" presents an exercising manner of ownership authorizations in order to ensure fulfillment of the liability. The contract cause on the fiduciary transfer of ownership is specific, and consists in securing the claim. ${ }^{7}$ Fiduciary contract as an fixture contract does not have an independent purpose, but serves to the implementation of the other principal

\footnotetext{
1 Prof.Dr.Abdulla Aliu,"E Drejta Sendore",Prishtina,2014.,p.,401

${ }^{2}$ Andrija Gams, Nesto o fiducijarnim pravnim poslovima, Anali Pravnog fakulteta u Beogradu, 1960, p.34.

3 Abdulla Aliu cited act.p.403.

${ }^{4}$ Velimirovic Mihailo, Ugovor o fiducijanom obezbedjenju trazbine,Pravni zivot No.11/1998, p.532.

${ }^{23}$ Lj.Djurovic, Ugovor o fiducijarnom prenosu svojine, Pravni zivot, No.10/1998. p.824.-.825.

6 Lj. Djurovic,lbid

${ }^{7}$ N.Gavella et.al., stvarno parvo, svezak drugi, Zagreb, 2007, p.469-470.
} 
contract in which the debtor's obligation is based. The purpose, of which the fiduciary transfer of ownership is made, is the provision of the foreseen claim with the principal contract (most often with the contract on the credit or loan).

For this we consider that the contract on the fiduciary transfer of ownership is a legal transaction cause, which constitutes the legal basis on the transfer of the ownership for the securing purposes, where the cause is outside the contract itself. ${ }^{1}$

\section{FIDUCIARY TRANSFER OF OWNERSHIP IN COMPARATIVE RIGHT}

Notwithstanding the fact that the codes of civil law do not regulate this type of security, today is represented in many legal systems, such as developed countries (Germany, Austria, Switzerland) and in transition countries (Poland, Czech Republic, Montenegro, Croatia, Slovenia and Macedonia). There are many fundamental differences in the implementation of this institute. In Germany, this form of security has wider application, since the many years of of legal practice and the support of the doctrine, have responded in many questions which arise in practice. ${ }^{2}$

German law distinguishes between the fiduciary transfer of ownership for the purpose of managing and the fiduciary transfer of ownership for the purpose of securing the claim. At the fiduciary transfer of ownership for the purpose of management, the fiduciary exercises the right of ownership in the interest of the fiduciary, while at the fiduciary ownership for the purpose to secure the claim, the fiduciary for the purpose to secure the movable property follows its credit interests towards the fiduciary for the purpose of securing that the claim will be paid at the noticed moment. In case of transfer of movable property into ownership for security purposes, the creditor and the debtor enter into a special contract under which the creditor cannot change or dispose the property and must keep it as a pledge, and in case of debt repayment, it is liable to return the pledge into the debtor's property. Otherwise, the transfer of ownership for the purpose of securing the creditor's claim can be extended so that not only claims are secured but all future claims of the secured party towards secured grantor or the claims of other creditors towards secured grantor (concerned clause). The German Civil Code only indirectly refers to the fiduciary transfer of the right and does not contain any provision in terms of form for this transfer. Legal practice allows the fiduciary to have real-legal protection against the fiduciary's creditors. Thus, the fiduciary may, prior to the fiduciary's insolvency, exclude this property from the bankruptcy measure, if the fiducuary's creditors enter into execution for the fiduciary's property, he can oppose it, since he is the final owner of the property. The fiduicary may, dispite his obligation, have the final power to possess such property in relation to third person, since his legal position exceeds the economic and legal goals of his work. ${ }^{3}$

France, after three decades and many unsuccessful legal efforts, finally, in 2007, regulated the fiduciary, with supplements and amendaments of the FCC. ${ }^{4}$ In addition to the general type, in French law there are also two independent fiduciary modalities: fiducie-sûreté and fiducie-gestion. The first is applied for the purpose of securing the execution of the liability. The second is applied for the purpose of managing union credits. ${ }^{5}$ The specificity of the fiduciary security claim in French law consists in that fiduciary security can only be contracted by legal persons in the tax on profit regime (Article 2014.CCa). Fiduciary can only be the financial institution (banking and security legal persons, state monetary and financial institutions), while there is no limit on the fiduciary side (Article $2015 \mathrm{CCa}$ ). Fiduciary security.Claim fiduciary security is required to be registered in the public register within one month from the date of contract conclusion (Article 2019.CCa).

The Swiss Code on Obligations. Where the agent acting on the principal's behalf acquires claims in his own name against third parties, such claims pass to the principal provided he has fulfilled all his obligations towards the agent under the agency relationship. ${ }^{6}$

Swiss doctrine and legal practice accepts the fiduciary transfer of ownership and the claim transfer for the purpose of securing the claim, but provided that this transfer be made on the basis of the actual will of the parties. The fiduciary transfer of ownership enables the beneficiary to acquire the full ownership. However, if the fiduciary transfer of ownership is created

\footnotetext{
1 D. Stojanovic, Prenosenje svojine u cilju obezbedjenju kredita, Pravni zivot, no.5-6/1993. God. f. 621

2 Mr.Povlakic, quoted paragraph, p.198-199.

${ }^{3}$ D.Borkovic-Stojanovic,Svojina radi obezbedjenja potrazivanja-fiducijarna svojina, Pravni zivot,br.10/98,p.381-382

${ }^{4}$ See Article 2011-2031 of FCC

${ }^{5}$ Lyczkowska, Karolina, The New Regime of Fiducie in French Law, in the Light of the Last Reforms (El Nuevo Régimen de Fiducie en el Derecho Francés a la Luz de las Ultimas Reformas) (Spanish) (January 1, 2010). InDret, Vol. 1, 2010. Available at

SSRN: https://ssrn.com/abstract=1565553/

6 The Swiss Code on Obligations, Article 401.
} 
through constitum possesorum, it has no legal effect on the third person, if by this had as purpose of avoiding and violating the pledge law norms. Therefore, fiduciary transferring of ownership does not bind all parties, especially not creditors of the alienator of property, but it is applied between the parties. ${ }^{1}$

Austrian legal theory has been shared on the issue of permissibility of fiduciary contract. Controversial was the cause of this legal contract or its suitability to be a legal basis for the transfer of ownership. According to one of the parties, fiducie is unlawful because there is no purpose of final transfer of ownership. Others see the causese in fiducie itself. Ownership is transferd with the purpose of securing the claim, to return back, if the secured claim is properly met. ${ }^{2}$

Fiduciary transfer of ownership has been accepted by Poland and Czech Republic with various legislative decisions. Fiduciary security in the Czech Republic is not a non-possessory property of security. In Poland the fiduciary transfer of ownership is based on banking law.

Greece has also approved the security of property transfer claims in order to secure and cessation of security purpose, without claiming for publicity of those secured claims. ${ }^{3}$

In the Republic of Croatia, the fiduciary security of claims is presented in three forms: fiducie with a legal-binding effect, permitted by the disputes of the liability relations, the fiduciary security of the claims in the form of the prior owner and the last owner with real-legal effect, regulated by the Law on Property and Other Real Rights and Judicial and Notary security with the transfer of ownership, regulated by the Execution Act of the Republic of Croatia. ${ }^{4}$

In the Republic of Slovenia, the fiduciary transfer of ownership is regulated by the real-legal code, where for the establishment of this institute is necessary the agreement of parties in notarial form. The feature of the Slovenian law is that the fiduciary transfer of ownership is allowed only for movable properties. ${ }^{5}$

In the group of states in which the fiduciary transfer of ownership is regulated for the security purpose also includes Montenegro, where in 1996 was established the Law on the Fiduciary Transfer of Ownership (the provisions of which were later incorporated into the Law of 2009 on real-legal relationship). ${ }^{6}$

In Montenegro Law the fiduciary transfer of ownership for the purpose of securing the claim is regulated in a different way, depending on whether the subject of the fiduciary property is movable or immovable property. According to the Law on real-legal relationshqip, fiduciary ownership in movable property is obtained by entering into a contract on the fiduciary transfer of ownership (Article 353, paragraph 1). The property remains in the possession of the fiduciary, according to the rules on the fictitious delivery of the property through the constitutum possessorium. Fiduciary ownership in the immovable property is obtained based on the contract on fiduciary transfer of ownership, with cadastral registration, a note that it is a matter of fiduciary transfer of ownership (Article 353, paragraph 2 and Article 354).

\section{FIDUICARY SECURITY SUBJECT}

Subject of fiduciary security may be individually defined moveable properties and immovable properties. Fiduciary security is extended in entire property, with the inseparably fruits, in constituent parts and the additionals of the property. Fiduciary ownership according to the rules on the extension in terms of subject of fiduciary security extends also to further improvements. Rules on fruit apply if the defaulted debtor in the moment of claim notice does not fulfill his liability to the fiduciary, when it reaches the final moment of aquiring the ownership by the fiduciary. Thus, until the moment of the final acquisition of the fiduciary, the right to usufruct the fruit (upon separation of the fruit from principal property) belongs to the fiduciary that enjoys direct power on the property. Rules defining fiduciary transfer of ownership comply first and foremost with the rules of the registred pledge and the mortgage, in which the debtor remains in possession of the pledged property and is authorized to usefruct the fruits provided by the property. ${ }^{7}$ Similar to Montenegrin law, both Macedonian and Croatian law have foreseen that in addition to movable property, as subject of fiduciary transfer of ownership may also be immovable

\footnotetext{
${ }^{1}$ Mr. sc. Zrinka Radi, Ibid.

2 D.Arandjelovic,O fiducijarnim pravnim poslovima,Arhiv za pravne i drustvene nauke,Beograd 1926,p.342.

${ }^{3}$ Mr. sc. Zrinka Radić, quoted paragraph.p.1022

4 "Narodne Novine RH" no.91/96, no.57/96.

5 Stvarno -pravni zakonik (SPZ, Uradni list Reublike Sllovenije 87/2002), cl.201-209.

${ }^{6}$ SI. List RCG. no. 19/09, sl.List RCG.no. 23/96.

${ }^{7}$ Lj. Djurovic, quoted paragraph, p.817.
} 
properties. In the business practice, the fiduciary transfer of ownership represents the representative form of security of bank loans, in addition to the mortgage, because by immovable property the creditor's demand from the principal contract (more often banks as a creditor) is seriously guaranteed and it is enabled the collection by the value of property charged in the moment of claim notice arrival, without the Court participation. With the analogous application of the rules on the acquisition of ownership by the non-owner, the acquisition of fiduciary ownership by the non-owner is possible in movable properties. ${ }^{1}$

\section{CONTENT OF THE CONTRACT ON FIDUCIARY TRANSFER OF PROPERTY}

The rights and obligations of the contracting parties make the contents of the contract on the fiduciary transfer of ownership. A Fiduciary has the right to complete the insurance, the sale of the item prematurely due to its destruction or loss of value, the right to demand the delivery of the item and its sale if the debtor does not fulfil its obligation upon receiving the request, the right to hold the item, the right of collection, the right to request the establishment of the sequestration institute, the obligation to return the surplus, the obligation of conduct under customary commercial law. The fiduciary has the right to possess, use the item and harvest the fruit, the obligation to store the item with the attention of the good housekeeper, the obligation to hand over the item if its debt is not paid prior to the deadline, the obligation of informing the creditor on the changes in the item etc. ${ }^{2}$

\section{PROPOSALS DE LEGE FERENDA}

The task of legal science is to propose the reform of existing legal institutes or the introduction of new institutes by which the real problems of the society shall be solved at a lower cost or more efficiently. Science has the privilege to propose the introduction of a new legal institute into the juridical order, whereby legal responsibility is borne by policy, while the task of science is to find the technical components accepted for the realization of this political enterprise. However, legal science must offer a new solution that will be in line with the functioning of the legal order and the principles on which it is based. This delicate task of juridical science especially It comes into play with regard to fiduciary affairs. Do we need the type of legal work that implies legitimizing the non-compliance of the legal form and its economic content, and the need for an ancillary legal purpose for securing the claim. ${ }^{3}$ The author of this paper is of the opinion that this institute should be regulated by a special law or be included in the new Civil Code of the Republic of Kosovo for many reasons.

The comparative advantages of fiduciary transfer of ownership include comparative doctrines in which, as an example of the implementation of the fiduciary transfer of ownership in the French Civil Code, the reason for the implementation is stated as "the explicit acceptance of the fiduciary relationship itself has caused France a lot of damage in the economic competition with other countries."

In Kosovo neither legal doctrine nor court practice have not deal with the institute of fiduciary transfer of ownership. However, some elements of the existence of the Institute of Fiduciary Transfer of Property are found in the Law on Obligational Relationship of the Republic of Kosovo. ${ }^{5}$ And Article 429 which, inter alia, foresees the provision for security purposes. "If a claim is assigned as security for the recipient's claim against the assignor the recipient shall be obliged to act with the diligence of a good businessperson or the diligence of a good manager in collecting the assigned claim, and after collection to deliver the surplus to the assignor once the amount required for repayment of the recipient's claim there against has been kept. In the present case, the object of the agreement represents a non-obligational right, but the express regulation of the assignment with legal provisions constitutes an argument for accepting the effect of the fiduciary transfer of ownership belonging to the affiliated trust group, respectively this institute should be governed by a special law.

Republic of Kosovo by drafting the Law on Property and Other Real Rights (hereafter: LTDPS) in $2009^{6}$ in our law has foreseen the pledge, pledge without a possession-institute which by effect is similar to fiduciary contracts, as well as the

\footnotetext{
1 Tamara Djurdjic, Fiducijarni prenos prava svojine, Zbornik radova Pravnog fakulteta u Novom Sadu, 2/2011, p.488.

2 T.Djurdjic, ibid.

${ }^{3}$ Dr.Atila Dudas, 0 celishodnosti zakonskog uredjenja fiducijarnog prenosa svojine u pravu Srbije,Zbornik radova Pravnog fakulteta u Novom Sadu,1/2014,p.222.

${ }^{4}$ Dr.Bojan Pajtic, paper cited.p.133.

5 Official Gazette of The Republic Of Kosovo / No. 16/19 JUNE 2012, Prishtina Law No. 04 / L-077 On The Obligational Relationship.

6 Official Gazette of The Republic Of Kosovo / Prishtina: Year IV / No. 57/04 AUGUST 2009 Law No. 03 / L-154 On Property And Other

Real Rights Assembly of Republic of Kosovo.
} 
mortgage. Whereas, pursuant to Article 14 of the Law on Registration of Pledge in the Register for Movable Items subject to registered pledge may be any movable property of a material value as well as any right that can be legally transferred. ${ }^{1}$

One of the reasons why the institute of Fiduciary transferring should be regulated by special law in Kosovo is that LTDPS has a restrictive stand towards the creditor in the contract on the non-public pledge, respectively, brings it to a more unfavourable position in comparison to its position as a fiduciary in the fiduciary contract. Thus, with Article 130 of the LTDPS it is envisaged as follows: The agreement, which is concluded prior to the achievement of the secured claim is null if it determines that in the event of non-payment after obtaining the secured claim the insured good passes to the ownership of the assignee; or the secured good to be sold at a certain price. So in the contract on the pledge, we have limitations in relation to the creditor, while these barriers do not exist for the creditor in the fiduciary transfer of ownership. He, as a fiduciary, in case of non-fulfilment of the requested claim, has all property authorizations in the insured item, like any other title holder.

The fiduciary ownership of the creditor provides higher security than the non-dividend pledge because it becomes the owner of the item, while the ownership over the fiduciary item enables easier gain of the possession of the item and more efficient execution of the demand if the fiduciary does not meet his obligation on time. The question that these two institutes, the fiduciary transfer of ownership and the non-dividend pledge, have similar effects is not a sufficient argument for the non-legal regulation of the institute of Fiduciary transfer of ownership. In addition to the non-dividend pledge, in parallel, the Fiduciary transfer of ownership should be regulated as both institutes would be new institutes in our legal order, while both serve for the same purpose, but there are many differences between them and the practice should be allowed to decide what to accept.

Another reason is that the fiduciary transfer of ownership due to insurance represents a safe and efficient means of securing the claim. Security lies both on the side of the debtor and the creditor. When it comes to movable items, the debtor is insured with the possession of the charged item (by which he secures his debts, but also with its use it is possible to pay the debt), by applying the rules for the fictitious handover through constitutum possessorium, as well as by registering a fiduciary contract in a public register with the note that it is about being fiduciary charged of the item. In the aspect of immovable properties, the required security is achieved by registering in the public books of immovable property with the note that it is a matter of fiduciary transfer of ownership. It is the fastest and most convenient tool for carrying out the claim, without the activation of a slow and quite expensive court enforcement mechanism.

The regulation of this institute with positive provisions would make it possible to harmonize and approximate the legislation of Kosovo in the field of civil law with the European Union legislation.

\section{CONCLUSION}

The author in this paper deals with the analysis of the Institute of Fiduciary Transfer of Property in order to secure the claim in contemporary law. Fiduciary transfer of ownership for the purpose of securing the claim represents the earliest real mean of securing the claim. Fiducia cum creditore disappeared under the influence of Christian ideology in Justinian's right, and consequently, the terms referring to that institute were erased by digesters in all classical texts and replaced by other terms, mainly pignus. This was due to the non-existence of the guarantee for the debtor that the ownership would be returned after the fulfilment of the obligation towards the creditor. In contemporary law, the application of fiduciary law is updated and, as a rule, the fiduciary transfer of ownership in order to secure the claim is a special type of non-dividend pledge and regulated under the provisions of the pledge. It has found the country in the rights of the country of the region (Macedonia, Montenegro, Croatia and Slovenia), while in some euro-western countries it is applied mostly in the field of civil and commercial law. The author of this paper points to the advantages of contemporary fiduciary as a means of securing the claim and proposes the regulation of this institute by a special law or the same institute to be included and standardized in the new Civil Code of the Republic of Kosovo.

\section{Bibliography and Literature}

[1] Asllan Bilalli\&Bedri Bakalli- Roman law -p.338-339, 2015-Prishtina.

[2] Prof.Dr.Abdulla Aliu,"E Drejta Sendore",Prishtina, 2014.,p.,401.

[3] Andrija Gams, Nesto o fiducijarnim pravnim poslovima, Anali Pravnog fakulteta u Beogradu, 1960, p.34.

\footnotetext{
1 Law No. 04/L-136 On Registration Of Pledge In The Register For Movable Property, 2012.
} 
[4] Dr.Atila Dudas, 0 celishodnosti zakonskog uredjenja fiducijarnog prenosa svojine u pravu Srbije,Zbornik radova Pravnog fakulteta u Novom Sadu,1/2014,p.222.

[5] D.Arandjelovic, O fiducijarnim pravnim poslovima,Arhiv za pravne i drustvene nauke,Beograd 1926,p.342

[6] Dr.Bojan Pajtic "Problem Dopustenosti fiducijarnog prenosa svojine u nasem pravu", Zbornik radova Pravnog Fakulteta u Novom Sadu 1/2017, p.126.

[7] D.Borkovic-Stojanovic,Svojina radi obezbedjenja potrazivanja-fiducijarna svojina,Pravni zivot,No.10/98,p.381-382.

[8] D. Stojanovic, Prenosenje svojine u cilju obezbedjenju kredita, Pravni zivot, No.5-6/1993. p. 621.

[9] Dr.Ejup Statovci, The right to pledge-comparative aspects, 1988, p.37.

[10] Gavella, Nikola; Josipović, Tatjana; Gliha, Igor; Belaj, Vlado; Stipković, Zlatan, Stvarno pravo, Narodne novine, Zagreb, 2007., p. 471.

[11] Dr. Nataša Hadžimanović, Kritički prilog o pitanju mogućnosti nekauzalnog i neakcesornog uređenja prava obezbeđenja Nova Pravna Revija Časopis za domaće, njemačko i evropsko pravo, No.2/2012, p.39.

[12] Petrak, Marko, Koncepcija generalne vindikacijske tuţbe u rimskoj pravnoj tradiciji i de lege ferenda, Zbornik Pravnog fakulteta u Zagrebu, No. 5-6/2013., p. 1054.

[13] Petrak, Marko, Rimska pravna tradicija i hrvatska pravna kultura, u: Rimsko pravo i Europa, Golden marketingTehniĉka knjiga, Zagreb, 2007., p. 176

[14] Mihnea-Dan Radu, Fiducia: From Fides to trust and the new Romanian Civil Code Regulation, Valahia University - Law Study,Volume xx.Issue 2012,p,239.

[15] Mangatchev, Ivan P., Fiducia Cum Creditore Contracta in EU Law (September 16, 2009). Available at SSRN: https://ssrn.com/abstract=1474199 or http://dx.doi.org/10.2139/ssrn.1474199.

[16] Kombe Bosombisa, Cynthia, La Protection Du Fiduciant (The Protection of the Settlor) (December 20, 2014). Available at SSRN: https://ssrn.com/abstract=2664839 or http://dx.doi.org/10.2139/ssrn.2664839/

[17] Povlakić, Meliha, Fiducijarno vlasništvo u usporednom pravu i sudskoj praksi, Zbornik Pravnog fakulteta Sveucilišta u Rijeci, No. 1/2003., p. 196.

[18] Romac, Ante, rimsko parvo,Zagreb, 1998,p.224.

[19] Lyczkowska, Karolina, The New Regime of Fiducie in French Law, in the Light of the Last Reforms (El Nuevo Régimen de Fiducie en el Derecho Francés a la Luz de las Ultimas Reformas) (Spanish) (January 1, 2010). InDret, Vol. 1, 2010. Available at SSRN: https://ssrn.com/abstract=1565553/

[20] Stanojevic Obrad."Rimsko Pravo", Beograd 1988-p.218.

[21] Stojcevic Dragoljub, „Rimsko Privatno pravo“, Savremena Administracija,Beograd, 1985, p. 250.

[22] Lj.Djurovic, Ugovor o fiducijarnom prenosu svojine, Pravni zivot, No.10/1998, p.824.-.825.

[23] Tamara Djurdjic, Fiducijarni prenos prava svojine, Zbornik radova Pravnog fakulteta u Novom Sadu, 2/2011, p.488.

24] Velimirovic Mihailo, Ugovor o fiducijanom obezbedjenju trazbine,Pravni zivot No.11/1998, p.532.

[25] Vladetic Srdjan, „Fiducija u rimskom pravu I savremeni fiducijarni poslovi“, Doktorska Disertacija,Pravni fakultet Universiteta u Beogradu, Beograd, 2010, p. 243.

[26] Mr. sc. Zrinka Radić: Uzroci heterogenosti besposjedovnih osiguranja tražbina na pokretninama i pravima, Zbornik radova Pravnog fakulteta u Splitu, 52, 4/2015., p. 1009.

[27 ] Pravna Encikopedija,Beograd,1989,p.378.

[28] Official Gazette of The Republic Of Kosovo / No. 16/19 June 2012, Prishtina Law No. 04/L-077 On Obligational Relationship.

[29] Official Gazette of The Republic Of Kosovo / Prishtina: Year Iv / No. 57/04 August 2009 Law No. 03/L-154 On Property And Other Real Rights Assembly of Republic of Kosovo.

[30] Law No. 04/L-136 On The Registration Of A Pledge In The Registry Of Movable Property, 2012

[31] SPZ, Uradni list Reublike Sllovenije 87/2002.

[32] Narodne Novine RH, No. 91/96, No. 57/96.

[33] SI. List RCG. No. 19/09., sl.List RCG.No. 23/96.

[34] Swiss Code on Obligations. 